\title{
Vitamin D Deficiency among Arab Community in North Israel: A Cross- Sectional Study
}

Z Armaly ${ }^{1 *}$, A Jabbour ${ }^{1}$, A Abd El Qader ${ }^{1}$, M Alhaj ${ }^{1}$, B Bisharat ${ }^{1}$, Z Abassi $^{2}$, M Zaher ${ }^{1}$ and A Bowirrat ${ }^{1 *}$

${ }^{1}$ EMMS Nazareth-The Nazareth Hospital, Nazareth, Israel

${ }^{2}$ Department of Physiology, faculty of medicine, Technion Institute of Technology, Israel

\begin{abstract}
Objectives: Plethora of studies had described a global widespread vitamin D inadequacy. Studies have established that the prevalence of vitamin $D$ deficiency is unexpectedly high in the Middle East. We aimed to determine the prevalence and the risk factors of vitamin D deficiency in Nazareth- Hospital Employees and Arab Football League.
\end{abstract}

Design: Population-based cross-sectional study was performed on 367 apparently healthy employees and 40 control football players. Serum levels of $25(\mathrm{OH}) \mathrm{D}$, parathyroid hormone, calcium, phosphate and Body mass index were measured in summer. The LIAISON® $25 \mathrm{OH}$ vitamin D assay uses immunoassay (CLIA) technology. Student's $t$ test, Pearson $r$ and one way ANOVA were used.

Results: Unexpectedly vitamin D deficiency was diagnosed on the basis of laboratory values in $91 \%$ of the hospital employees and in $72.5 \%$ of the football players $(25(\mathrm{OH}) \mathrm{D}<30 \mathrm{ng} / \mathrm{ml})$. The frequencies of deficiency $(<20 \mathrm{ng} / \mathrm{ml})$, insufficiency $(20-30 \mathrm{ng} / \mathrm{ml})$, and sufficiency $(>30 \mathrm{ng} / \mathrm{ml})$, were $(59 \%, 32 \%$ and $9 \%)$ for employees and $(25 \%, 47.5 \%$ and $27.5 \%$ ) for players respectively. PTH and BMI results were $60 \mathrm{pg} / \mathrm{ml}$ and $26 \mathrm{~kg} / \mathrm{m} 2$ for the employees and $38 \mathrm{pg} /$ $\mathrm{ml}$ and $23 \mathrm{~kg} / \mathrm{m} 2$ for the players respectively. Comparing vitamin D, PTH values among Hospital employees versus football players the levels of vitamin D were significantly lower among hospital employees, whereas, the levels of PTH were significantly higher $[(p<0.001(95 \% \mathrm{Cl}-8.27$ to -2.469$)$ and $[(p<0.0001) 95 \% \mathrm{Cl} 10.15$ to 23.9$)]$, respectively. The hospital employees' correlation between (PTH and vitamin $5 \mathrm{D}$ ) and (BMI and vitamin D) were $(r=-0.17 ; 95 \% \mathrm{Cl}-0.273$ to $-0.061, p=0.002)$ and $(r=-0.2 ; 95 \% \mathrm{Cl}-0.3$ to $-0.09, p<0.001)$ respectively

Conclusions: Vitamin D deficiency is a global health problem even in sunny climate. Long term strategies to address this issue should include public education, national health policies through food fortification, and vitamin D supplementation. Reappraisal of the range of the vitamin $D$ level worldwide is warranted, and the need for reliable cutoff criteria to describe vitamin $\mathrm{D}$ deficiency is required.

Keywords: Vitamin D deficiency; Prevalence; Employees; Football players

\section{Introduction}

In the past decade, important steps forward the study of the authentic vitamin $\mathrm{D}$ pathophysiology have been made. In addition to its vital role in the bone homeostasis, skeletal development and maintenance, multiple facts are mounting, that vitamin $\mathrm{D}$ provides widespread beneficial effects, and not only on bone tissues, but to almost all tissues throughout the body and that the concentrations needed for optimal health are almost certainly higher than previously reported [1]

Simultaneously, vitamin D provides to the extra skeletal structures and the relatively high dominancy of insufficient levels of vitamin D have been largely unknown by both clinicians and patients [2].

Chemically all forms of vitamin D are secosteroids share a close structural and functional resemblance to steroids. Fundamentally, the term vitamin $\mathrm{D}$ indicates to a pair of biologically inactive precursors of a critical micronutrient. They are vitamin D2 or Ergocalciferol or 25 -hydroxyvitamin D $[25(\mathrm{OH}) \mathrm{D}]$ and vitamin D3 or Cholecalciferol or 1,25-dihydroxyvitamin $\mathrm{D}$ [1,25(OH)2 D] [3].

Vitamin D2 is produced by the action of UV-B- irradiation on ergosterol, a 5,7-diene phytosterol, which is synthesized by fungi and phytoplankton but not in the animal kingdom [4]. It is the major form of dietary vitamin D in humans[5] and its bioavailability from UV-B-irradiated and vitamin D boosted mushrooms, revealing a new promising approach of improving the vitamin $\mathrm{D}$ maintenance in the general population[6,7].

Vitamin D3 is produced with peak synthesis occurring between
295 and 297 nanometers [8] and this is the form that goes to work by attaching itself to vitamin $\mathrm{D}$ receptors present throughout the body. Vitamin D is acquired both through nutritional means (10-20\%) and by the cutaneous synthesis under the action of sunlight (80-90\%) [9].

Vitamin D has multifunctional activities with pleiotropic effects on calcium and phosphorus metabolism, hence it's vital role in the bone homeostasis, and in safeguarding against an array of diseases acts in concert with other nutrients and hormones to support healthy bone renewal - an ongoing process of mineralization and demineralization which, when awry, shows up as rickets in children and osteomalacia or osteoporosis in adults [10-18].

Although there is no consensus or some disagreement on optimal levels of $25(\mathrm{OH}) \mathrm{D}$ as measured in serum, vitamin $\mathrm{D}$ deficiency is defined by most experts as a 25(OH)D below $20 \mathrm{ng} / \mathrm{mL}$ and vitamin D insufficiency as a $25(\mathrm{OH}) \mathrm{D}$ level of $21 \mathrm{ng} / \mathrm{mL}$ to $29 \mathrm{ng} / \mathrm{mL}[9,19-23]$.

${ }^{*}$ Corresponding authors: Prof. Abdalla Bowirrat, EMMS Nazareth-The Nazareth Hospital, Nazareth, Israel, Tel: +972-4-6028827; Fax: +972-4-6028882; E-mail: bowirrat@netvision.net.il

Dr. Zaher Armaly, EMMS Nazareth-The Nazareth Hospital, Nazareth, Israel, Tel: +972-4-6028827; Fax: +972-4-6028882; E-mail: zaherarmaly@nazhosp.com

Received November 29, 2011; Accepted December 14, 2011; Published December 16, 2011

Citation: Armaly Z, Jabbour A, El Qader AA, Alhaj M, Bisharat B, et al. (2011) Vitamin D Deficiency among Arab Community in North Israel: A Cross-Sectional Study. J Nutr Disorders Ther 1:105. doi:10.4172/2161-0509.1000105

Copyright: (C) 2011 Armaly Z, et al. This is an open-access article distributed under the terms of the Creative Commons Attribution License, which permits unrestricted use, distribution, and reproduction in any medium, provided the original author and source are credited. 
Deficiency of vitamin D can be attributed to different reasons: It can result from inadequate nutritional intake coupled with inadequate sunlight exposure and other disorders that limit vitamin $\mathrm{D}$ absorption and impair the conversion of vitamin D into active metabolites.

The growing understanding of the multifunctional roles of vitamin $\mathrm{D}$ throughout the body has provided new insights and shed lights on the function of this vitamin.

It has been estimated that 1 billion people worldwide are affected by various degrees of vitamin D deficiency [24]. This global concealed epidemic phenomenon is more harmful than previously thought, rationalize the serious attention attributed to this vitamin [25].

Despite the plentiful sunlight year round in the Middle East $\left(15^{\circ}\right.$ $36^{\circ} \mathrm{N}$ ), it has one of the highest rates of vitamin D deficiency worldwide.

One of the first studies was conducted in university students and elderly from Saudi Arabia, and revealed a mean 25(OH)D level ranging between 4- $12 \mathrm{ng} / \mathrm{mL}$ [26] The mean 25(OH)D level was near $10 \mathrm{ng} /$ $\mathrm{mL}$ in Lebanese, Saudi, Emirati and Iranian women. [27-29] A similar mean was recorded in elderly Lebanese [30], Kuwait [31] and the United Arab Emirates (UAE) [32].

It was $35 \%$ for a vitamin $\mathrm{D}$ level below $10 \mathrm{ng} / \mathrm{mL}$ in a study of elderly subjects from a geriatric hospital in Israel [33] and between 60-65\% in Lebanon, Jordan and Iran [34], and was $48 \%$ for a cut-off less than $15 \mathrm{ng} / \mathrm{mL}$ in subjects from Tunisia [35]. Hovsepian et al. from Isfahan city, Iran, and Bener et al. from Qatar reported a high prevalence of vitamin D deficiency (50.8\%)[36] and (68.8\%)[37] respectively.

In France, $14 \%$ of healthy adults have serum $25(\mathrm{OH}) \mathrm{D}$ concentrations below $12 \mathrm{ng} / \mathrm{mL}$ [38], and 29\% in Finland [39]. Some population subgroups may be at greater risk of vitamin D deficiency, e.g., the elderly and subjects with darker skin pigmentation or subjects living in regions with low levels of sunlight. Reported prevalence levels within high risk groups rises to $47 \%$ amongst elderly people in Europe [40] and 42\% amongst Afro-American women in the USA [41]. Because the scarcity of population data on vitamin D status in Israeli Arabs, the objective of this study was to conduct an unique novel study to assess the prevalence of vitamin D deficiency among the NazarethE.M.M.S Hospital Employees and among professional football Arab players living in the same metropolitan area in north Israel.

\section{Methods}

This current population-based cross-sectional study was performed during the summer of 2011 after obtaining signed written informed consent at the study enrollment from all participants. 367 (60\% females) apparently healthy employees and 40 control healthy males' football players recruited to undergo a blood test, nutritional and activity assessments during the summer period (Table 1).

Venous blood samples were collected into plain tubes, and serum was separated and stored at $-70^{\circ} \mathrm{C}$ until analysis. The hospital employees were divided in subgroups according to their profession as follow: 46(12.5\%) Physicians [mean age $\pm \mathrm{SE}=47.5 \pm 1.25$ ]; 182(49.5\%) Nurses [mean age $\pm \mathrm{SE}=40.25 \pm 0.89$ ] and 139(38\%) Administration [mean age $\pm \mathrm{SE}=40.27 \pm 0.89$ ] (Table 1$)$. The football players were divided according to their team location as follow: $7(20 \%)$ from Nazareth town [mean age $\pm \mathrm{SE}=22.5 \pm 4.69$ ]; 20(50\%) from Sakhnin town [mean age $\pm \mathrm{SE}=24.5 \pm 4.1$ ] and $13(30 \%)$ from Arrabeh town [mean age $\pm \mathrm{SE}=$ 24.8 \pm 5.3 ] (Table 1). Complete physical examination for every subject was performed and serum levels of 25-hydroxy vitamin D (25(OH)D), parathyroid hormone (PTH), calcium, phosphate, Body mass index (BMI), and nutritional intake, and lifestyle variables that constitute potential risk factors for vitamin $\mathrm{D}$ deficiency were evaluated. The LIAISON $25 \mathrm{OH}$ Vitamin D TOTAL Assay uses chemiluminescent immunoassay (CLIA) technology for the quantitative determination of 25-hydroxyvitiamin D and other hydroxylated vitamin D metabolites in human serum was used for the assessment of vitamin D levels. Assay results were used in conjunction with other clinical or laboratory data to assist the clinician in making individual patient management decisions in an adult population. The subjects were classified as vitamin D-deficient, -insufficient, or -sufficient on the basis of $25(\mathrm{OH})$ D concentrations of $<20 \mathrm{ng} / \mathrm{mL}, 20-30 \mathrm{ng} / \mathrm{mL}$, and $>30 \mathrm{ng} / \mathrm{mL}$, respectively, according to recent consensus [43].

Descriptive results are presented as mean \pm SE. Student's $t$ test was used to compare the differences between the hospital employees and the football player's subjects. We used Pearson $r$ to determine the correlation between 25(OH)D and PTH levels and to characterize other relationships among variables. One way ANOVA multiple comparison tests were used to compare vitamin D levels and age. $P$ values $<0.05$ were considered significant.

\section{Results}

A total of 407 subjects were evaluated during the study (Table 1). The mean $\pm S E$ age (in years) for hospital employees' subjects versus the control football players' subjects was $42.67 \pm 0.96$ versus $23.3 \pm$ $4.58(\mathrm{p}<0.05)$. Of the total number of hospital employees surveyed, 26 out of 367 subjects (7\%), are under medications for chronic diseases [(13/26 have Hypertension); (7/26 have type 2 diabetes mellitus and hypertension) and (6/26 have type 2 diabetes mellitus)]. Using one way ANOVA Nonparametric Turkey's multiple comparison test, no significant differences were observed between the chronic diseases and vitamin D levels ( $\mathrm{p}>0.05)$ (Table 2).

We found a significant higher vitamin status in football players $(n=40)$ compared to the total healthy employees $(n=341)$ after the

\begin{tabular}{|c|c|c|c|}
\hline \multirow[b]{2}{*}{$\mathrm{N}^{\circ}(\%)$} & \multicolumn{3}{|c|}{ Hospital Employees subgroups } \\
\hline & $\begin{array}{l}\text { Physicians } 46 \\
(12.5 \%)\end{array}$ & $\begin{array}{l}\text { Nurses } 182 \\
(49.5 \%)\end{array}$ & $\begin{array}{l}\text { Administration } 139 \\
(38 \%)\end{array}$ \\
\hline Age Mean \pm SE & $47.5 \pm 1.25$ & $40.25 \pm 0.75$ & $40.27 \pm 0.89$ \\
\hline Females \# ( \% ) & $7(15 \%)$ & $136(75 \%)$ & $77(55 \%)$ \\
\hline \multirow[t]{2}{*}{ Males \# ( \% ) } & $39(85 \%)$ & $46(25 \%)$ & $62(45 \%)$ \\
\hline & \multicolumn{3}{|c|}{ Football Teams subgroups } \\
\hline $\mathrm{N}^{\circ}(\%)$ & $\begin{array}{l}\text { Nazareth } \\
7(20 \%)\end{array}$ & $\begin{array}{l}\text { Sakhnin } \\
20(50 \%)\end{array}$ & $\begin{array}{l}\text { Arrabeh } \\
13(30 \%)\end{array}$ \\
\hline Age Mean \pm SE & $22.5 \pm 4.7$ & $24.5 \pm 4.1$ & $24.8 \pm 5.3$ \\
\hline
\end{tabular}

Table 1: Demographic data of the participants.

\begin{tabular}{|l|l|l|l|}
\hline & Vitamin D $(\mathbf{n g} / \mathbf{m l})$ & PTH $(\mathbf{p g} / \mathbf{m l})$ & BMI $\left(\mathbf{k g} / \mathbf{m}^{2}\right)$ \\
\hline Employees $(n=367)$ & $19.47 \pm 0.4$ & $59.9 \pm 2.5$ & $26.2 \pm 0.2$ \\
\hline Phys. $(n=46)$ & $21.27 \pm 1.1$ & $60.97 \pm 3.3$ & $27.1 \pm 0.2$ \\
\hline Nurses $(n=182)$ & $* 17.93 \pm 0.7$ & $61.1 \pm 2.5$ & $25.8 \pm 0.3$ \\
\hline Admin. $(n=139)$ & $* 20.9 \pm 0.6$ & $58.05 \pm 5.1$ & $26.3 \pm 0.5$ \\
\hline Players $(n=40)$ & $24.84 \pm 1.2$ & $37.80 \pm 2.3$ & $23.2 \pm 0.2$ \\
\hline Nazareth $(n=7)$ & $24.10 \pm 2.4$ & $31.84 \pm 4.1$ & $23.07 \pm 0.6$ \\
\hline Sakhnin $(n=20)$ & $23.95 \pm 1.4$ & $39.44 \pm 3.4$ & $23.5 \pm 0.2$ \\
\hline Arrabeh $(n=13)$ & $26.61 \pm 2.5$ & $39.08 \pm 4.3$ & $22.7 \pm 0.2$ \\
\hline
\end{tabular}

Table 2: The table shows the (mean \pm SE) of the vitamin D, PTH and BMI for the total Employees and their subgroups [(Physicians, Nurses and Administration and for the football players and their subgroups resident at (Nazareth, Sakhnin and Arrabeh)]. The table also shows a statistically significant difference in the level of vitamin $D$ in favor of the subgroups of Administration employees $(20.9 \pm 0.6)$ versus the levels of vitamin $D$ among Nurses $(17.93 \pm 0.7)$. The statistical significant difference is marked by red star $\left.\left(^{*}\right), p<0.05\right)$. 
exclusion of those who carry chronic diseases [ $(n=26),(p=0.0003)]$. In addition, when we compared the levels of vitamin $\mathrm{D}$ of the healthy employees $(n=341)$ with the diseased employees $(n=26)$, there was no statistical significant differences between the two groups $(\mathrm{p}=0.76)$. Additionally, females employees (220/367) were divided according to the traditional religious uncovered head versus covered head hair (200/220 versus 20/220), respectively. Females employees with covered hair had statistically significant lower vitamin $\mathrm{D}$ status compared to those with uncovered hair ( $95 \%$ CI- 12.2 to $3.84, \mathrm{p}<0.001$ ), (Figure 1). Hospital employees were also divided to nonsmokers versus smokers (288/367 vs 79/367) respectively, the levels of vitamin D were significantly higher among smokers (95\% CI 0.063 to $4.474, \mathrm{p}=0.04)$ (Figure 2). The football players' subjects do sportive activity starting their day at 10.00am and performing outdoor football games at stadium at least 5 hours a day with their face, legs, arms, and forearms exposed to sunlight without using sun cream. Suboptimal vitamin D status observed in $91 \%$ of the hospital employees and in $72.5 \%$ of the football players $(25(\mathrm{OH}) \mathrm{D}<30 \mathrm{ng} / \mathrm{ml})$, (Figure 3$)$. The frequencies of

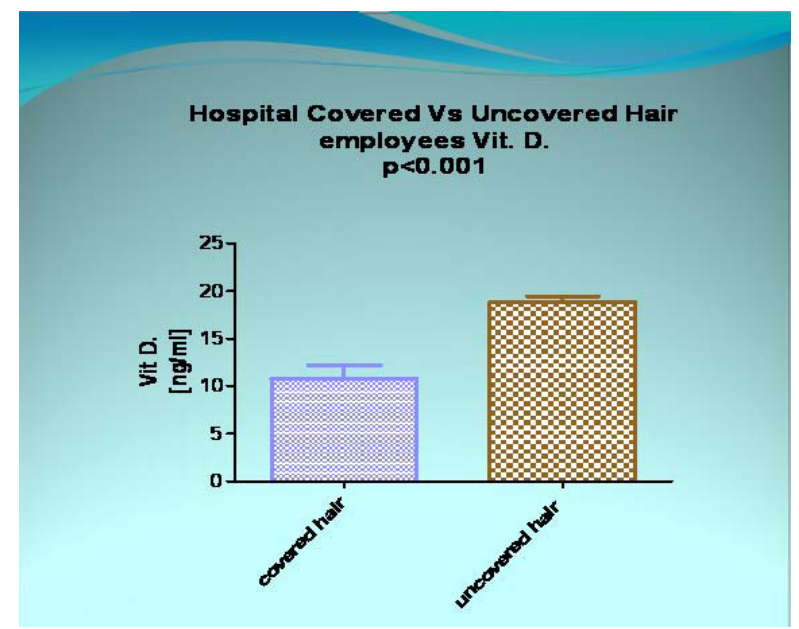

Figure 1: Hospital hair covered employee's vitamin D levels Versus uncovered hair employees.

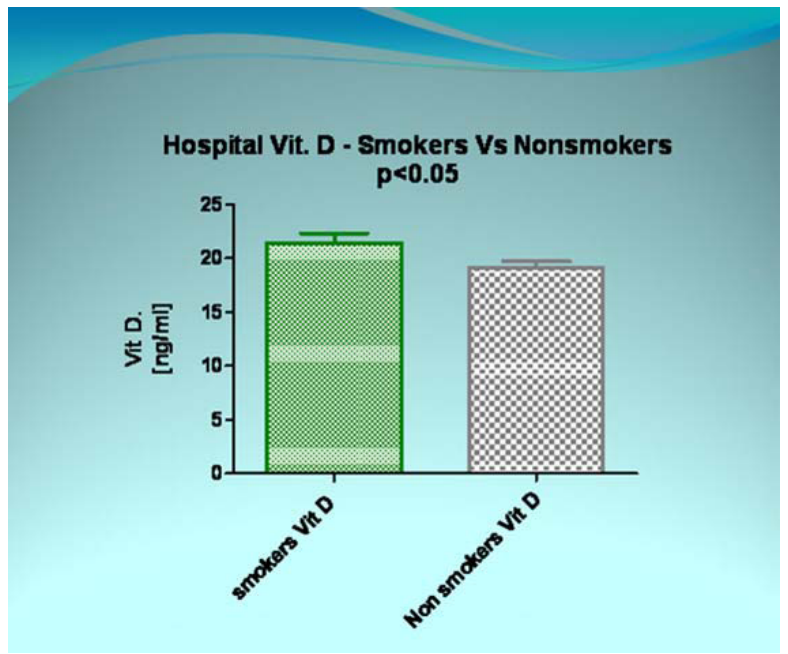

Figure 2: Comparison of Hospital Vitamin D values among smokers VS nonsmokers.

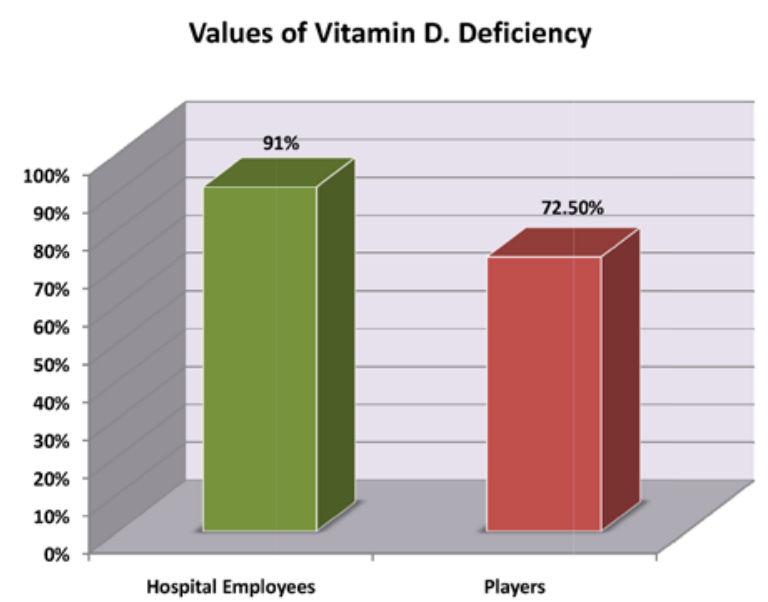

Figure 3: Vitamin D deficiency among hospital employees $(91 \%)$ versus $(72.5 \%)$ among football players.

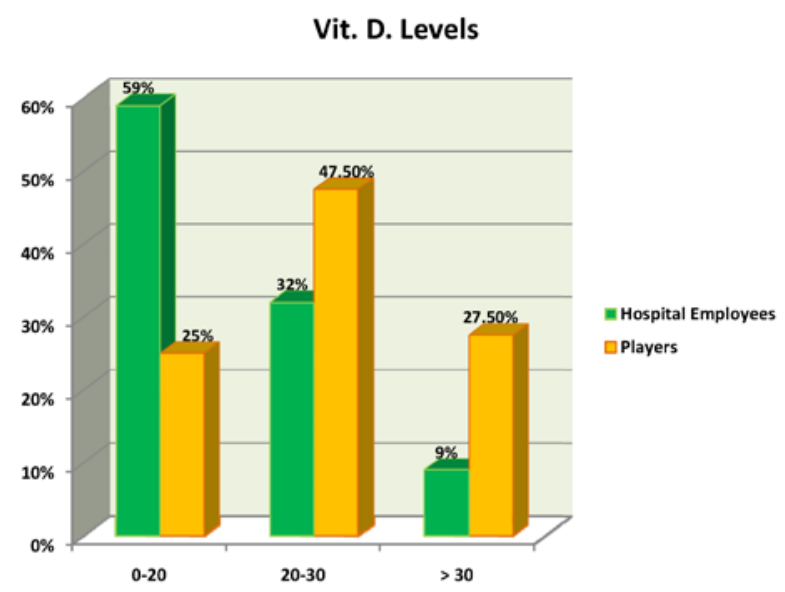

Figure 4: The frequencies of deficiency ( $<20 \mathrm{ng} / \mathrm{ml})$, insufficiency $(20-30$ $\mathrm{ng} / \mathrm{ml}$ ), and sufficiency ( $>30 \mathrm{ng} / \mathrm{ml}$ ) of vitamin $\mathrm{D}$, among hospital employees and players.

deficiency (<20 ng /ml), insufficiency (20-30 ng/ml), and sufficiency (>30 ng/ml), were divided as $(59 \%, 32 \%$ and $9 \%)$ for employees and (25\%, $47.5 \%$ and $27.5 \%)$ for players respectively, the differences were statistically significant $[(\mathrm{p}<0.001(95 \% \mathrm{CI}-8.27$ to -2.469$)]$ (Figure 4$)$. In comparison with football players and employees vitamin $\mathrm{D}$ levels versus age, there was no significant correlations $(p=0.972),(p=0.84)$ respectively.

Body Mass Index (BMI) ranges [normal range (18.5-25)] were 26 units for the employees versus 23 units for the players (Table 2). Comparing the vitamin D deficiencies, PTH values between employees vs. players, the values were statistically significant and pronouncedly evident among employees in comparison with the players values $[(\mathrm{p}<0.001(95 \%$ CI -8.27 to -2.469$)$ and $[(\mathrm{p}<0.0001) 95 \%$ CI 10.15 to 23.9)] (Figure 5 and Figure 6). PTH values; [normal values (10-55pg/ $\mathrm{ml}$ )]; were $60 \mathrm{pg} / \mathrm{ml}$ for the employees versus $38 \mathrm{pg} / \mathrm{ml}$ for the football players (Table 2). The difference of the prevalence of subjects with secondary hyperparathyroidism (value $>55 \mathrm{pg} / \mathrm{ml}$ ) between employees and players was calculated (Figure 7). The result demonstrates that (17.5\%) of players and (38\%) of hospital employees have PTH values 


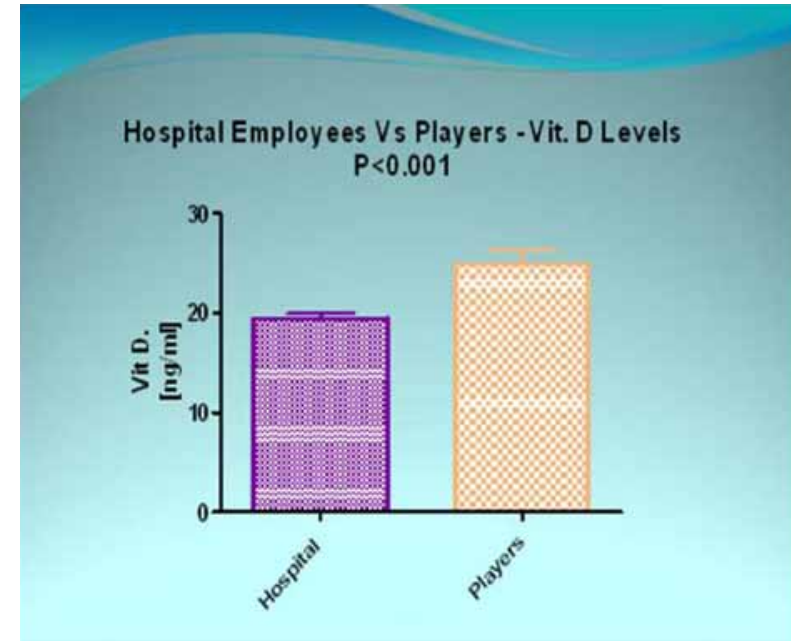

Figure 5: Hospital employee's vitamin D levels among employees and players.

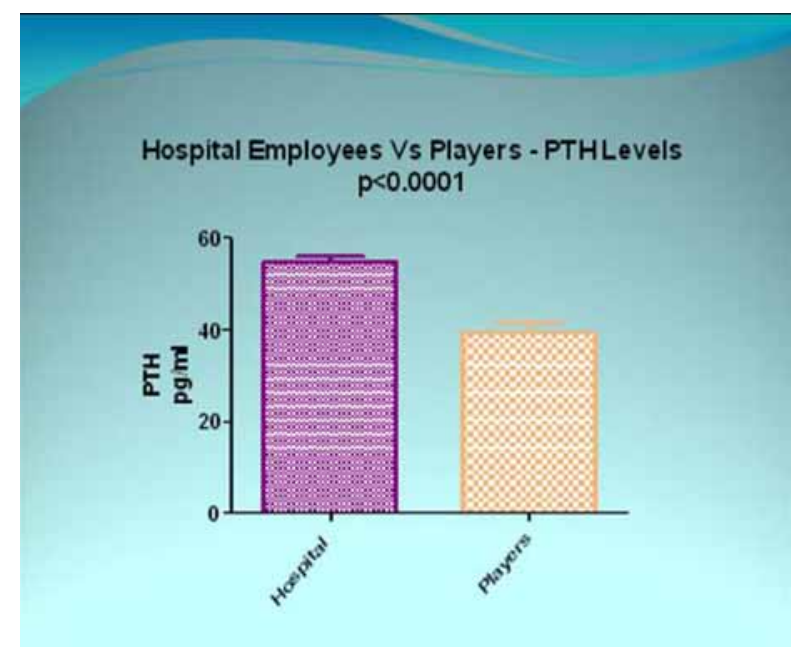

Figure 6: The comparison of Parathyroid hormone (PTH) levels among employees and football players.

up to $55 \mathrm{pg} / \mathrm{ml}$. This result shows a clinically relevant portion of subjects with vitamin $\mathrm{D}$ deficiency. Indeed, a secondary hyperparathyroidism based on low vitamin $\mathrm{D}$ status mean a real clinical sign for a deficiency. The hospital employees' correlation between (PTH and vitamin D) and (BMI and vitamin D) were ( $\mathrm{r}=-0.17 ; 95 \% \mathrm{CI}-0.273$ to $-0.061, \mathrm{p}=0.002)$ and $(\mathrm{r}=-0.2 ; 95 \% \mathrm{CI}-0.3$ to $-0.09, \mathrm{p}<0.001)$ respectively, (Figure 8 and Figure 9).

\section{Discussion}

To the best of our knowledge, this is the first epidemiological report of prevalence of vitamin D deficiency among professional Arab medical employees and football players in Israel. The novelty of the current study is the unexpectedly high prevalence of vitamin $\mathrm{D}$ deficiency [(employees vs. players); (91\% vs. $72.5 \%)$ ] respectively. The overstate assumption that football players and professional medical employees may have normal values of vitamin $\mathrm{D}$ was refuted by our study. In fact, it was astonishing to find low concentrations of $25(\mathrm{OH}) \mathrm{D}$ in healthy hospital employees in a country with ample sunshine.

Smokers who spend more than five minutes under the sunlight have higher levels of vitamin D comparing to non smokers who stay indoors $(p<0.05)$. Moreover, a statistical significant effect of vitamin $D$ levels were found in favor of uncovered head versus covered head hair $(\mathrm{p}<0.001)$. Our results concur with other previous studies that have inverse correlation between BMI and vitamin D deficiency $[10,11]$. Indeed, vitamin D plays an important role in diverse physiologic functions such as bone homeostasis [10,11]. Therefore, the likely disturbances due to vitamin D deficiency and the therapeutic potential of vitamin D were expanding [13-17].

Determining vitamin D status can be a challenging task. Defining different levels of vitamin $\mathrm{D}$ according to health consequences rather than population means is the preferred method but has led to an ongoing debate about what constitutes "normal" or "optimal" $25(\mathrm{OH})$ D levels. Several criteria have been used to define sufficient $25(\mathrm{OH})$ D levels, including the level associated with optimal suppression of circulating PTH levels, greatest calcium absorption, highest bone mineral density (BMD), lowest rates of bone loss, falls, or fractures [43].

\section{The difference of the prevelance of Hospital Employees Vs Players with secondary Hyperparathyrodism (PTH $>55 \mathrm{pg} / \mathrm{ml}$ )}

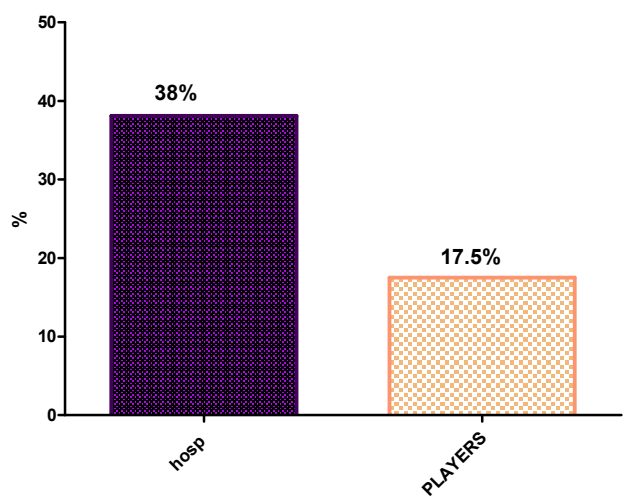

Figure 7: The figure shows the difference of the prevalence of subjects with secondary hyperparathyrodism $(\mathrm{PTH}>55 \mathrm{pg} / \mathrm{ml}$ ) between employees and players. It demonstrates the clinically relevant portion of employees and football players with vitamin D deficiency (38\% vs $17.5 \%)$, respectively.

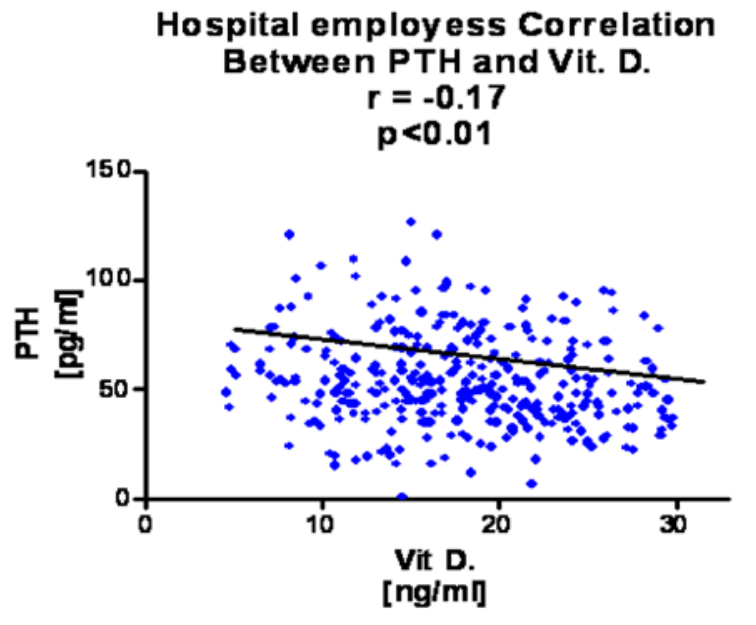

Figure 8: Hospital employees correlation between PTH and Vitamin D. 
Hospital Employees Correlation Between BMI and Vit. D. $r=-0.2$ $P<0.001$

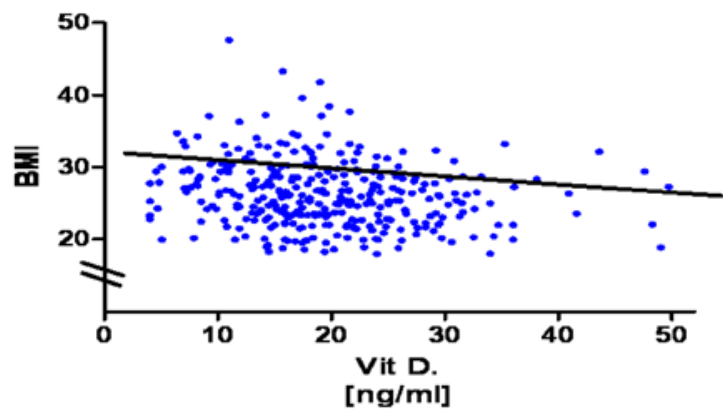

Figure 9: Hospital employee's correlation between BMI and Vitamin D.

Until the 1990s, the criterion for appropriate vitamin D nutrition was simply the absence of overt rickets or osteomalacia [44]. Now, circulating 25- 16 hydroxyvitamin $\mathrm{D}[25(\mathrm{OH}) \mathrm{D}]$ concentrations are the appropriate measure of vitamin $\mathrm{D}$ nutritional status.

It is wrong to assume that simply because individuals live at southern latitudes, they need less vitamin D supplementation-some people actively avoid exposing skin to the sun, and the supply of dermal vitamin $\mathrm{D}$ is a function of sun exposure, amount of skin surface exposed, and dark skin pigmentation.

In a study by Plontikoff et al. [45] in their Minnesota-based study had deficient levels of vitamin $\mathrm{D}$ on patients with non-specific musculoskeletal pain and it was found that $100 \%$ of African Americans, East Africans, Hispanics, and American had deficient levels of vitamin $\mathrm{D}<20 \mathrm{ng} / \mathrm{ml}$. Vasikaran et al. [46] found that $34 \%$ of blood donors age 18-67 years in Australia had vitamin D of $<20 \mathrm{ng} / \mathrm{ml}$. In a study by Tangpricha et al. [47] they observed that $36 \%$ of young adults are vitamin $\mathrm{D}$ deficient reflecting that wide distribution of vitamin $\mathrm{D}$ deficiency even among young people. Vitamin D deficiency is common in the Middle East. Woodhouse et al. [48] reported a low vitamin D level in Saudi Arabia population despite sunny days are almost all year round. In recent study by Sadat-Ali et al. [49] they found $25-37 \%$ of healthy Saudi men have vitamin D deficiency.

This study was conducted on healthy professionals including physicians, nurses, administrations and professional football players. The mean age was 40.5 years vs. 23.8 respectively. The study revealed that $91 \%$ of hospital employees and $72.5 \%$ of the players have vitamin D $<30 \mathrm{ng} / \mathrm{ml}$. This is an extremely high prevalence of vitamin D deficiency among young individuals with no musculoskeletal complaints. Participants with low vitamin D level were called for counseling and treatment. Very few studies conducted on health care professionals are reported in the literature.

During 2007-2008 a similar study was performed among health care staff at Hamad Medical Corporation in Doha, Qatar, it was observed that $(96.5 \%$ of the study sample had vitamin D level of $<30 \mathrm{ng} / \mathrm{ml}, 87 \%$ had vitamin D level of $<20 \mathrm{ng} / \mathrm{ml}$, while $54.7 \%$ had severe deficiency with a level of $<10 \mathrm{ng} / \mathrm{ml}$, and $20 \%$ had vitamin D below the lower limit of detection [3ng/ml]) [50]. In Boston Medical Center, it was observed that $32 \%$ of healthy students, physicians, and residents were found to be vitamin $\mathrm{D}$ deficient, despite adequate nutrition regime [51]. Another study conducted by Jancin on 35 internal medicine house staff at Oregon Health Sciences University, Portland, revealed that $51.4 \%$ of them were vitamin D deficient [52]. In a study on pregnant and lactating women who were thought to be immune to vitamin $\mathrm{D}$ deficiency since they took a daily prenatal multivitamin containing 400 IU of vitamin D (70\% took a prenatal vitamin, $90 \%$ ate fish, and $93 \%$ rink approximately 2.3 glasses of milk per day; ( $73 \%$ of the women and $80 \%$ of their infants were vitamin D deficient (vitamin D level, $<20 \mathrm{ng}$ per milliliter) at the time of birth [53].

Only $5 \%$ of our hospital employees reported an average daily time spent outdoor of more than hour and their vitamin D did not differ from others who reported spending less time outdoors.

This could be because they are spending this time in the shade indoor or not getting enough exposure to the sun. In sports medicine vitamin $\mathrm{D}$ deficiency has become a hot topic recently. This study helps to show that it is a problem not limited to elderly or less healthy patients. It is a problem among professional athletes, such as National Football League (NFL), as well. In accordance with the levels of our NFL results of vitamin D deficiency, our NFL $(n=40$, mean age $=24 y)$, from northern Israel showed that $72.5 \%$ - had abnormal vitamin D levels of less than $30 \mathrm{ng} / \mathrm{mL}$. 10 players had deficient levels $(<20 \mathrm{ng} / \mathrm{mL})$ and an additional 19 players had levels consistent with insufficiency (20-30ng/mL). 11 players had values within normal limits (> 30ng/ $\mathrm{mL}$ ). Comparable vitamin D levels were reported from 89 professional football players (mean age $=25 \mathrm{y}$ ) from the New York National Football League (NFL) team in the spring of 2010 found an alarming percentage of players - $80.9 \%$ - had abnormal vitamin D levels, of less than $32 \mathrm{ng} /$ ml. 27 players had deficient levels $(<20 \mathrm{ng} / \mathrm{mL})$ and an additional 45 had levels consistent with insufficiency (20-31.9 ng/mL). 17 players had values within normal limits $(>32 \mathrm{ng} / \mathrm{mL})$.

In addition, all players sustaining injuries that caused them to miss at least 1 practice or game had vitamin D levels that were significantly lower than players without muscle injury. Among the $18 \%$ of players who sustained a muscle injury in the previous season, all had statistically significant lower vitamin D levels, compared with those without muscle injury. There were no other statistically significant differences between those who did and did not sustain the injuries. The mean vitamin $\mathrm{D}$ level among players who did not sustain a muscle injury was $24.7 \mathrm{ng} /$ $\mathrm{mL}$ (range, 9.0 to $46.0 \mathrm{ng} / \mathrm{mL}$ ), and the mean level among the 16 players who did suffer a muscle injury was $19.9 \mathrm{ng} / \mathrm{mL}$ (range, 8.0 to $33.0 \mathrm{ng} /$ $\mathrm{mL})(P<.04)$ [54]. In contrary, among the Arab Football League no muscle injury was registered. All our football players were in good health condition and participate in all the practice and games.

A subsequent study examined the data on vitamin D insufficiency in 98 athletes and dancers (age range 20 to 30 years) in a sunny country. $73 \%$ of the participants had vitamin D insufficiency, and insufficiency was greatest among dancers and basketball players (94\% in each group) $[55,56]$. In consensus with other studies, our study demonstrates high prevalence of vitamin D deficiency among our NFL and showed no link to an increased rate of muscle injury. This research joins other international findings pointing to a need to examine and address vitamin $\mathrm{D}$ insufficiency and deficiency not only in football players, but in other athletes as well. In conclusion, vitamin D deficiency is a global public health problem across all life stages with deleterious immediate and latent manifestations. Long term strategies to address this silent disease should include public education, national health policies for screening whole population and prevention through food fortification, and treatment through vitamin D supplementation. In addition, reappraisal of the range of the vitamin D level globally is warranted. Furthermore, we stress the need for a reliable cutoff criteria to describe 
vitamin $\mathrm{D}$ deficiency in the south of the Equator, since single cutoff value may be suitable for populations living in sunny climate with dark skin with relatively insufficient production of vitamin D or - viceversa - but might be inappropriate for others living in shadowy climate with bright skin with high production of vitamin $\mathrm{D}$, (since more than $80 \%$ of vitamin $\mathrm{D}$ is produced in the skin by a photoreaction on exposure to ultraviolet B light from the sun).

\section{Summary}

Our aims were to conduct a novel study to assess the prevalence of vitamin D deficiency among hospital employees and among professional football players living in the same metropolitan area in Israel whose geographical alignment includes latitude of $31^{\circ} 30^{\prime} \mathrm{N}$, and 13 hours of sunlight in summer and 10 hours in winter, taking into account the impact of different variables; such as biochemical measurements, traditions, environmental risk factors on the development of vitamin D deficiency, in an area with plentiful sunlight throughout the year, and the strategies that should be implemented to prevent and treat this deficiency. High vitamin D deficiency was diagnosed in $91 \%$ of the hospital employees and in $72.5 \%$ of the football players on the basis of laboratory values. When comparing vitamin $\mathrm{D}, \mathrm{PTH}$ values among Hospital employees versus football players the levels of vitamin D were significantly lower among hospital employees $(p<0.001)$, whereas, the levels of PTH were significantly higher $(\mathrm{p}<0.0001)$. In the light of these findings we have proposed to discuss whether the reassessment of the cutoff criteria already used to describe vitamin D deficiency worldwide, is adequate for warm climate. In addition, the high prevalence of vitamin $\mathrm{D}$ deficiency among the above-mentioned populations raises the question of whether vitamin D supplements and food fortification should be given to these groups on a routine basis even in a sunny country such as Israel.

\section{Strengths and Limitations}

To the best of our knowledge, the current study is the first to investigate and compare the prevalence, biochemical measures, customs, environmental risk factors on the development of vitamin $\mathrm{D}$ deficiency among hospital employees and professional football players in Israel. This study also brings forth clearly the low dietary calcium intake and the limited exposure to sunlight of both the hospital employees and football players, which requires a need for screening and supplementations of vitamin $\mathrm{D}$ for both groups, even to those who live in sunny countries, because this may be a simple way to help prevent injuries and maximize muscle function, especially among athletics. The study was cross-sectional, and that limits the generalizability of these results. Furthermore, there are methodological limitations in this study since our sample of hospital employees and football players are a sample of convenience, more subjects in all age groups of both sexes in urban and rural locations in different parts of the country should be studied in the future. In addition, the strikingly high prevalence of vitamin $\mathrm{D}$ deficiency in this population necessitate radiographic assessments, another biomarkers of vitamin D status, in a subset of patients such as football players to detect their bone demineralization, considering the fact that all deficiencies were subclinical.

\section{References}

1. Holick MF (2004) Sunlight and vitamin D for bone health and prevention of autoimmune diseases, cancers, and cardiovascular disease. Am J Clin Nutr 80: $1678-1688$

2. Grant WB, Holick MF (2005) Benefits and requirements of vitamin D for optima health: a review. Altern Med Rev 10: 94-111.

3. Heaney RP (2004) Functional indices of vitamin D status and ramifications of vitamin D deficiency. Am J Clin Nutr 80: 1706-1709.
4. Holick MF (2011) Calciotropic hormones and the skin: a millennium perspective. J Cosmet Sci 52: 146-148.

5. Holick MF (2004) Vitamin D: importance in the prevention of cancers, type diabetes, heart disease, and osteoporosis. Am J Clin Nutr 79: 362-371.

6. Urbain P, Singler F, Ihorst G, Biesalski HK, Bertz H (2011) Bioavailability of vitamin D from UV-B-irradiated button mushrooms in healthy adults deficient in serum 25-hydroxyvitamin D: a randomized controlled trial. Eur J Clin Nutr 65: 965-971.

7. Ko JA, Lee BH, Lee JS, Park HJ (2008) Effect of UV-B exposure on the concentration of vitamin D2 in sliced shiitake mushroom (Lentinus edodes) and white button mushroom (Agaricus bisporus). J Agric Food Chem 56: 3671 3674.

8. Hume EM, Lucas NS, Smith HH (1927) On the Absorption of Vitamin D from the Skin. Biochem J 21: 362-367.

9. Bischoff-Ferrari HA, Giovannucci E, Willett WC, Dietrich T, Dawson-Hughes B (2006) Estimation of optimal serum concentrations of 25-hydroxyvitamin D for multiple health outcomes. Am J Clin Nutr 84: 18-28.

10. Holick MF (2002) Vitamin D: the underappreciated D-lightful hormone that is important for skeletal and cellular health. Curr Opin Endocrinol 9: 87-98.

11. Thacher TD, Clarke BL (2011) Vitamin D Insufficiency. Mayo Clin Proc 86: $50-60$.

12. Cannell JJ, Hollis BW, Zasloff M, Heaney RP (2008) Diagnosis and treatment of vitamin $D$ deficiency. Expert Opin Pharmacother 9: 1-12.

13. Hyppönen E, Läärä E, Reunanen A, Järvelin MR, Virtanen SM (2001) Intake of vitamin $D$ and risk of type 1 diabetes: a birth-cohort study. Lancet 358: 15001503.

14. Ardestani PM, Salek M, Keshteli AH, Nejadnik H, Amini M, et al. (2010) Vitamin D status of 6- to 7- year-old children living in Isfahan, Iran. Endokrynol Pol 61 : 377-382.

15. Bener A, Al-Ali M, Hoffmann GF (2009) Vitamin D deficiency in healthy children in a sunny country: associated factors. Int J Food Sci Nutr 60: 560-570.

16. Bhattoa HP, Bettembuk P, Ganacharya S, Balogh A (2004) Prevalence and seasonal variation of hypovitaminosis $\mathrm{D}$ and its relationship to bone metabolism in community dwelling postmenopausal Hungarian women. Osteoporos Int 15 : 447-451.

17. Wang TJ, Pencina MJ, Booth SL, Jacques PF, Ingelsson E, et al. (2008) Vitamin D deficiency and risk of cardiovascular disease. Circulation 117: 503-511.

18. Chapuy MC, Schott AM, Garnero P, Hans D, Delmas PD, et al. (1996) Healthy elderly French women living at home have secondary hyperparathyroidism and high bone turnover in winter. J Clin Endocrinol Metab 81: 1129-1133.

19. Malabanan A, Veronikis IE, Holick MF (1998) Redefining vitamin D insufficiency. Lancet 351: 805-806.

20. Thomas MK, Lloyd-Jones DM, Thadhani RI, Shaw AC, Deraska DJ, et al (1988) Hypovitaminosis D in medical inpatients. N Engl J Med 338: 777-783.

21. Glerup H, Mikkelsen K, Poulsen L, Hass E, Overbeck S, et al. (2000) Commonly recommended daily intake of vitamin $\mathrm{D}$ is not sufficient if sunlight exposure is limited. J Intern Med 247: 260-268.

22. Boonen S, Bischoff-Ferrari HA, Cooper C, Lips P, Ljunggren O, et al. (2006) Addressing the musculoskeletal components of fracture risk with calcium and vitamin D: a review of the evidence. Calcif Tissue Int 78: 257-270.

23. McKenna MJ (1992) Differences in vitamin D status between countries in young adults and the elderly. Am J Med 93: 69-77.

24. Holick MF (2007) Vitamin D deficiency. N Engl J Med 357: 266-268.

25. Prentice A (2008) Vitamin D deficiency: a global perspective. Nutr Rev 66: S153-S164.

26. Sedrani SH, Elidrissy A, Elarabi KM (1983) Sunlight and vitamin D status in normal Saudi subjects. Am J Clin Nutr 38: 129-132.

27. El-Hajj Fuleihan G, Deeb M (1999) Letter to the Editor. Hypovitaminosis in Sunny Country. N Engl J Med 340: 1840-1841.

28. Elidrissy AWTH (1991) Vitamin D deficiency rickets in Saudi Arabia. In Glorieux FM (ed) Rickets nestle nutrition workshop Series. Raven Press, New York 21: 223-231. 
Citation: Armaly Z, Jabbour A, El Qader AA, Alhaj M, Bisharat B, et al. (2011) Vitamin D Deficiency among Arab Community in North Israel: A CrossSectional Study. J Nutr Disorders Ther 1:105. doi:10.4172/2161-0509.1000105

29. Saadi HF, Nagelkerke N, Benedict S, Qazaq HS, Zilahi E, et al. (2006) Predictors and relationships of serum 25 hydroxyvitamin D concentration with bone turnover markers, bone mineral density, and vitamin $D$ receptor genotype in Emirati women. Bone 39: 1136-1143.

30. Arabi A, Baddoura R, Awada H, Salamoun M, Ayoub G, et al. (2006) Hypovitaminosis D osteopathy: Is it mediated through PTH, lean mass, or is it a direct effect? Bone 39: 268-275

31. Majid Molla A, Badawi MH, al-Yaish S, Sharma P, el-Salam RS, et al.(2000) Risk factors for nutritional rickets among children in Kuwait. Pediatr Int 42 : 280-284.

32. Dawodu A, Khadir A, Hardy DJ, et al. (2002) Nutritional rickets in UAE: an unresolved cause of childhood morbidity. Middle East Paediatr. 7: 12- 14.

33. Goldray D, Mizrahi-Sasson E, Merdler C, Edelstein-Singer M, Algoetti A, et al. (1989) Vitamin D deficiency in elderly patients in a general hospital. J Am Geriatr Soc 37: 589-592.

34. Mishal AA (2001) Effects of different dress styles on vitamin D levels in healthy young Jordanian women. Osteoporos Int 12: 931-935.

35. N. Meddeb, H. Sahli, M. Chahed, J. Abdelmoula, M. Feki, et al. (2005) Vitamin D deficiency in Tunisia. Osteoporos Int 16: 180-183.

36. Hovsepian S, Amini M, Aminorroaya A, Amini P, Iraj B (2011) Prevalence of vitamin $D$ deficiency among adult population of Isfahan city, Iran. J Health Popul Nur 29: 149-155.

37. Bener A, Al-Ali M, Hoffmann GF (2009) High prevalence of vitamin D deficiency in young children in a highly sunny humid country: a global health problem. Minerva Pediatr 61: 15-22.

38. M.-C. Chapuy, P. Preziosi, M. Maamer, S. Arnaud, P. Galan, et al. (1997) Prevalence of vitamin $\mathrm{D}$ in sufficiency in an adult normal population. Osteoporos Int 7: 439-443.

39. Lamberg-Allardt CJ, Outila TA, Kärkkainen MU, Rita HJ, Valsta LM, et al. (2001) Vitamin D deficiency and bone health in healthy adults in Finland: could this be a concern in other parts of Europe? J Bone Miner Res16: 2066-2073.

40. van der Wielen RP, Löwik MR, van den Berg H, de Groot LC, Haller J, et al. (1995) Serum vitamin D concentrations among elderly people in Europe. Lancet 346: 207-210

41. Nesby-O'Dell S, Scanlon KS, Cogswell ME, Gillespie C, Hollis BW, et al. (2002) Hypovitaminosis D prevalence and determinants among African American and white women of reproductive age: third National Health and Nutrition Examination Survey, 1988-1994. Am J Clin Nutr 76: 187-192.
42. Hollis BW (2005) Circulating 25-hydroxyvitamin D levels indicative of vitamin D sufficiency: implications for establishing a new effective dietary intake recommendation for vitamin D. J Nutr 135: 317-322.

43. Blumberg RW, Forbes GB, Fraser D, et al. (1963) The prophylactic requirement and the toxicity of vitamin D. Pediatrics $31: 512-525$.

44. Plotnikoff GA, Quigley JM (2003) Prevalence of severe hypovitaminosis D in patients with persistent, nonspecific musculoskeletal pain. Mayo Clin Proc 78 1463-1470.

45. Vasikaran SD, Sturdy G, Musk AA, Flicker L (2000) Vitamin D insufficiency and hyperparathyroidism in Perth blood donors. Med J Aust 172: 406-407.

46. Tangpricha V, Pearce EN, Chen TC, Holick MF (2002) Vitamin D insufficiency among free-living healthy young adults. Am J Med 112: 659-662.

47. Woodhouse NJY, Norton WL (1982) Low vitamin D levels in Saudi. Arabians King Faisal Specialist Hospital Medical Journal 2: 127-131.

48. Sadat-Ali M, AlElq A, Al-Turki H, Al-Mulhim F, Al-Ali A (2009) Vitamin D levels in healthy men in eastern Saudi Arabia. Ann Saudi Med 29: 378-382.

49. Mahdy S, Al-Emadi SA, Khanjar IA, Hammoudeh MM, Sarakbi HA, et al. (2010) Vitamin D status in health care professionals in Qatar. Saudi Med J 31: 71-77.

50. Tangpricha V, Pearce EN, Chen TC, Holick MF (2002) Vitamin D insufficiency among free-living healthy young adults. Am J Med 112: 659-662.

51. Jancin B (2003) Vitamin D deficiency common among physicians in training long- term risk to bone health. Skin \& Allergy News 34:55.

52. Lee JM, Smith JR, Philipp BL, Chen TC, Mathieu J, et al. (2007) Vitamin D deficiency in a healthy group of mothers and newborn infants. Clin Pediatr 46: $42-44$.

53. Larson-Meyer DE, Willis KS (2010) Vitamin D and athletes. Curr Sports Med Rep 9: 220-226.

54. Constantini NW, Arieli R, Chodick G, Dubnov-Raz G (2010) Clin J Sport Med 20: 368-371.

55. American Orthopaedic Society for Sports Medicine (AOSSM). Vitamin D Lower in NFL Football Players Who Suffered Muscle Injuries, Study Reports. June 10, 2011.

56. Dawson-Hughes B, Heaney RP, Holick MF, Lips P, Meunier PJ, et al. (2005) Estimates of optimal vitamin D status. Osteoporos Int 16: 713-716. 